\title{
Effective Selection of Resources for Construction using Program Tool
}

\author{
G. Dhanasekar, A. Sivakumar, L. Madhumitha, P. Karthikeyan
}

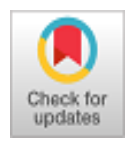

\begin{abstract}
In the Indian scenario construction industry facing a major problem is cost and time overrun. Effective time performance and cost performance are very important to execute the project in a successful manner by keeping them within the prescribed schedule and cost. Overall cost and duration of construction projects affected by the effective resource selection factor. This paper's objective is to rectify the improper selection of resources by a programming tool. Field survey and codebook study did collect the needed data to feed in the programming tool. The prepared tool gets distributed and making to access by every stakeholder of construction projects. This may result in the selection of construction resources as effectively. The term cost overrun in the resource part will be reduced.
\end{abstract}

Keywords: Cost overrun, Time overrun, Program tool, Android mobile application.

\section{INTRODUCTION}

Infrastructural projects in urban areas play a major role in the countries development. The migration of people from rural to urban areas for employment and educational purpose tends to population congestions in cities. Government plans for decentralization and developing nearby urban areas. Because of space scarcity, high rise buildings are essential for cope with people density in small areas. Commonly every high rise buildings are constructing for the scope of profit such as Institutional buildings, Industrial buildings, Residential apartments, and commercial buildings. From the period of building operation only the benefit which returns on investment will receive by respective investors. Because of cost and time overrun of those projects tends to the loss for the investors. Hence by effective selection and handling the resources will give good results for the project to finish within the estimated time cost.

Revised Manuscript Received on February 05, 2020.

* Correspondence Author

Mr. G. Dhanasekar*, Pursuing M.E Construction Engineering and Management, Department of Civil Engineering, Kongu Engineering College, Erode, Tamilnadu, India. dhana7284.7@gmail.com

Mr. A. Sivakumar, Assistant Professor, Department of Civil Engineering, Kongu Engineering College, Erode, Tamil nadu, India. sivakumarcivil36@gmail.com

Ms. L. Madhumitha, Pursuing M.E Construction Engineering and Management, Department of Civil Engineering, Kongu Engineering College, Erode, Tamilnadu, India. madhulogu1996@gmail.com

Dr. P. Karthikeyan, Assistant Professor, Department of Management Studies, Kongu Engineering College, Erode, Tamilnadu, India.ptp_karthi@kongu.ac.in

(C) The Authors. Published by Blue Eyes Intelligence Engineering and Sciences Publication (BEIESP). This is an open access article under the CC BY-NC-ND license (http://creativecommons.org/licenses/by-nc-nd/4.0/)
Construction site management, advanced techniques and methods, quality and available quantity of materials, the efficiency of construction equipment are the factors which influence the day to day productivity [1]. Reducing the wastages of resources will make the project as a profitable one. The three major resources that we concern in construction projects are Machinery, Manpower, and Materials.

\section{RESEARCH METHODOLOGY}

This research project carried out with a definite methodology by collecting literature relate to cost and time overrun of the construction industry. A field study was also conducted on various construction projects about their investment towards the resources and outturn of work from the respective resources and discussed with various stakeholders involved in resource management. To understand the current field practice and a disparity with standards and what the firm management expects from respective stakeholders about efficiency, productivity and material consumption. For rectify the problem a user friendly program tool was planned to prepare which easy to access and process.

\section{RESOURCES OF CONSTRUCTION}

Investment is the base resource for all construction projects. The objects which deciding the quantity of money for a project in construction are Labors, Raw materials, and construction equipment. This rather called Manpower, Materials, and Machinery.

\section{A. Machinery}

Machinery which is commonly named as construction equipment in the construction industry. It increases productivity and makes to complete the work easier than by doing manually. Day by day new innovations is found to make easier to do every work of the construction tasks. Usage of equipment gives more productivity result and reduces the error compare to work done by manually. High-level maintenance, care, and good skill are required for the operation of equipment. The particular list of work is repeatedly done in every construction project. Various construction equipment that available in markets are Drum machine mixer, Mobile concrete mixer, Asphalt, and concrete pavers, Backhoe loader, Cranes, Crawler dozers, loaders, Directional drills, Excavators, Forklifts, Telehandlers, Graders, Heating and cooling equipment,

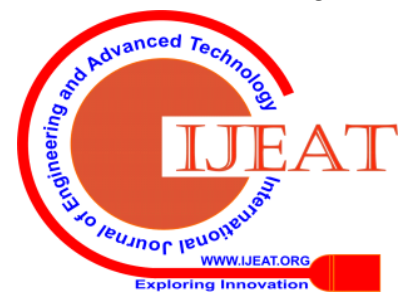




\section{Effective Selection of Resources for Construction using Program Tool}

Mining equipment, Riding compactors, Rollers, Riding trenchers, Scissor and boom lifts, Skid street loaders, Tractors, and wheel loaders. Backhoe loader and Excavator are the two common equipment using in most of

the construction projects for Earthwork excavation. Mobile concrete mixer and Drum machine mixer are the two common equipment using for the mixing of cement concrete.

\section{B. Manpower}

All three resources are relating to each other contribution of one another gives the exact result of what we want. Even automotive culture increased by machinery, construction labors are essential for the operation of equipment and other tasks. Whether advanced equipment is available in the market but the cost of purchase, operation and maintenance are very much higher compared to labor cost. The average work done hours by labor to complete the particular task is said to be productivity [2]. Depend on the nature of the task, categories of labors get classified and named with grades according to their skill set. Head Mason, Mason, Male mazdoor, Female mazdoor are the most common type labors involved in masonry, concrete, tile-laying and other related workers. Painter for Painting and Surface finishing work. Plumber for Pipeline fixing and plumbing works. Carpenter for Doors, windows fixing and other wood related works. Bar bender for the fabrication of steel and placing the reinforcement. Fitter and helper for shuttering and formwork. Electrician and helper for fixing electrical conduits and other electrical related works. Trained machinery operator for the handling of equipment. Works that repeatedly done in construction sites with large volumes are Masonry work, Cement concrete work, Plastering, Painting, and Tile lying.

\section{Materials}

All the other two resources work for these main resource materials to build the infrastructures. The requirement of the other two resources depends on the situation happens in the construction site. Quantity of material requirement is almost constant which already planned before execution. The number of wastages done by workers or equipment or by any other factor will result in the variation by exceeding the estimated quantity of materials used. Operational errors such as consuming less raw materials will affect the quality of work and quantity of work to finish. Actual material usage will not equal rather less than the estimated quantity of material usage. Civil work contractors purchase the raw materials as per the requirement of a particular job task before within a week of work. Quantity of purchase order level depends on the fund, availability storage area in a construction site, schedule of work and quantity of work. Works that repeatedly done in construction sites in large volumes are Masonry work, Cement concrete work, Plastering, Painting, Tile laying. Planning for the purchase of bulk raw materials is a crucial stage to make the projects as a profitable one.

Big infrastructural projects need a huge quantity of raw materials such as cement, fine aggregate, coarse aggregate, steel bars for reinforcement, masonry bricks or blocks, etc., Most of the construction contractors purchase the materials from direct factory outlet without interruption of dealers for discount and instant purchase. Raw materials production factory direct outlet offer more discounts on bulk purchase. Proper planning of materials by pre estimation of quantities helps to purchase bulk orders on raw materials. A small quantity of reorder levels, frequent transportation, loading and unloading charges will decrease by bulk orders. The pre estimation of a project starts from small works estimation by calculating the total quantity of raw material required for a particular quantity of work. Similar to manpower and machinery pre knowing the resource requirement helps to sign the contract with sub-contractors. The choice for machinery orders either by purchase or hire will select effectively.

\section{IV.COST AND TIME OVERRUN}

By completing the project within the estimated budget means the success of it [3]. Whereas every factor due to client, contractor, consultant, labor, materials, equipment and external factors affects the cost of the project especially to resources of the project by both directly and indirectly [4]. The client feels that it was a major problem that the project not complete within the budget and time [5]. A study on Jordan infrastructure projects identified the 20 main factors for delay and cost overrun. The factors variation in orders, labor availability, and cost of variation in orders were ranked in the top 20 [6]. Olawale and Sun (2010) identified nonperformance of sub-contractors, low skilled manpower, projects fraud and corruption were some factors within 21 factors that they found from a study [7]. Material procurement was found in the top five factors list from the study done on Ghana groundwater projects [8]. Long Le-Hoai (et al,) ranked the factor shortage of materials and skilled workers in his top list with SPSS software analysis where the study was done in Vietnam for delay and cost overrun in large construction projects [9].

\section{LITERATURE GAP ANALYSIS}

Most of the literature gives a clear view to study and understand the factors which are causing cost and time overrun of the construction industry. Authors from various countries express their views towards cost and time overrun of the construction industry in their countries. Factors causing cost and time overrun were listed and top factors were ranked as per the analysis they have done. Solutions that are theoretically written to recover from the problem. This research paper tends to repair the problem as practically by preparing a programming tool.

\section{VI.PROGRAM TOOL}

Now a day's every educated person having smartphones with them. Where machinery makes the heavy work as easier, human life strongly depends on software technology for browsing, communication, gaming, documentation, shopping, entertainment, etc.,

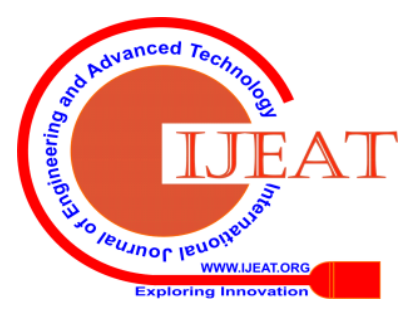


Tools that are prepared based on software program satisfies the requirement within some limited task. Choices that recommend for selecting the programming tool are Dynamic blog and Mobile application. A dynamic blog is a kind of active web page which development is controlled by an application server processing server-side scripts. Hence internet connection is necessary for the operation of the programming tool. Hence it will not accessible in remote areas where there is no internet connection.

Because of the factors familiarity, easy accessibility, user-friendly and economical smartphone-based mobile application program tool is the favorable option. Where most of the smartphone users like to use the Android operating system, which is simple to use rather than iOS and other operating systems, Android operating system based mobile application was planned to prepare. By using android studio software the tool was prepared with the help of application developing technicians. By feeding the extracted data for the standard quantity of work.

\section{DATA FOR PROGRAM TOOL}

The outturn of Machinery and Manpower resources per day is considered as productivity. Depend on the efficiency of machinery and skill set of labors the outturn varies. Whether profit or loss for particular work will decide from the report of outturn result. Standard working hours of a worker per day is 8 hours, but from the field survey in the construction scenario, there is no definite duration and time to work. Depends on the quantity of work, availability of labors the working time varies and duration of work increases and decreases than 8 hours. This will also match the machinery and its operator. The productivity of machinery used for Earthwork excavation were found by calculating the collected data in the field survey.

In Masonry, Concrete, Tile laying and other related works Head mason or Mason are the key persons to complete the task, the outturn depends on their skill set and speed of work. For masonry work Male mazdoor and Female mazdoor are supporting labors to prepare the workplace, mixing of cement concrete and mortar, conveying the raw materials from the storage area, etc., Numbers of supporting labors will be added depends on site conditions, distance to be covered for shifting the materials. Mason and Male mazdoor are the primary resources to complete the work. Depends on their daily wages and unit rate per work their outturn result defined.

Table 1 shows the minimum productivity of the machinery per day for 8 hours of work. Machinery which does not give this minimum amount of productivity given in the table then it seems to be a loss for the outturn. Depends on the obstacles in the construction sites leads to a mismatch of this productivity rate.

Table 1. Productivity of Machineries per day

\begin{tabular}{|c|c|c|c|c|}
\hline Equipment & \multicolumn{2}{|c|}{ Back hoe loader } & \multicolumn{2}{|c|}{ Excavator } \\
\hline $\begin{array}{c}\text { Nature of } \\
\text { Soil }\end{array}$ & Loose soil & $\begin{array}{r}\text { Hard } \\
\text { soil }\end{array}$ & Loose soil & $\begin{array}{r}\text { Hard } \\
\text { soil }\end{array}$ \\
\hline $\begin{array}{c}\text { Rate Per } \\
\text { Cubic feet (Rs) }\end{array}$ & 1 & 1.5 & 1 & 1.5 \\
\hline Rent per day & & & & \\
\hline
\end{tabular}

\begin{tabular}{|c|c|c|c|c|}
\hline (Rs) & 650 & 650 & 1350 & 1350 \\
\hline $\begin{array}{l}\text { Outturn in } \\
\text { Cubic feet } \\
\left(\mathrm{Cft} \text { or } \mathrm{ft}^{2}\right)\end{array}$ & 650 & 433.33 & 1350 & 900 \\
\hline $\begin{array}{c}\text { Outturn in } \\
\text { Cubic meter } \\
\left(\text { Cum orm }{ }^{2}\right)\end{array}$ & $\begin{array}{r}18.42 \\
\approx 18\end{array}$ & $\begin{array}{r}12.28 \\
\approx 12\end{array}$ & $\begin{array}{r}38.26 \\
\approx 38\end{array}$ & $\begin{array}{r}25.51 \\
\approx 25\end{array}$ \\
\hline
\end{tabular}

Table 2 represents the acceptable level of average productivity of labor per day for 8 hours of work done by Mason and Male mazdoor each 1 number.

Table 2. Productivity of Man power per day for Masonry works

\begin{tabular}{|l|l|l|}
\hline S.No & \multicolumn{1}{|c|}{ Name of the work } & Productivity in $\mathbf{~ m}^{2}$ \\
\hline 1 & 9 " thick Brick work wall & $06.90 \approx \mathbf{0 7 . 0 0}$ \\
\hline 2 & 4.5 " thick Brick work wall & $11.40 \approx \mathbf{1 1 . 5 0}$ \\
\hline 3 & 6 " Solid/Hollow block wall & $11.43 \approx \mathbf{1 1 . 5 0}$ \\
\hline 4 & 8" Solid/Hollow block wall & $08.26 \approx \mathbf{0 8 . 3 0}$ \\
\hline 5 & Autoclaved aerated concrete block & $07.43 \approx \mathbf{0 7 . 5 0}$ \\
\hline 6 & Coursed or Random Rubble masonry & $05.70 \approx \mathbf{0 6 . 0 0}$ \\
\hline 7 & Inner wall Plastering & $16.51 \approx \mathbf{1 6 . 5 0}$ \\
\hline 8 & Outer/Ceiling Plastering & $12.54 \approx \mathbf{1 2 . 5 4}$ \\
\hline 9 & Tile laying work & $08.90 \approx \mathbf{0 9 . 0 0}$ \\
\hline 10 & Paver block laying & $09.60 \approx \mathbf{0 9 . 5 0}$ \\
\hline
\end{tabular}

Table 3 represents the acceptable level of average productivity by a painter per day for 8 hours of work.

Table 3. Productivity of Man power per day for Painting works

\begin{tabular}{|c|l|l|}
\hline S.No & \multicolumn{1}{|c|}{ Name of work } & Productivity in $^{\mathbf{2}}$ \\
\hline 1 & White wash $1^{\text {st }}$ coat & $49.76 \approx \mathbf{5 0 . 0 0}$ \\
\hline 2 & White wash $2^{\text {nd }}$ coat & $55.80 \approx \mathbf{5 6 . 0 0}$ \\
\hline 3 & Water paint & $98.80 \approx \mathbf{1 0 0 . 0 0}$ \\
\hline 4 & Enamel paint & $78.40 \approx \mathbf{7 8 . 5 0}$ \\
\hline 5 & Primer & $98.80 \approx \mathbf{1 0 0 . 0 0}$ \\
\hline 6 & Putty & $49.76 \approx \mathbf{5 0 . 0 0}$ \\
\hline
\end{tabular}

Table 4 represents the quantity of materials required to do the particular quantity of respective works. Values are derived theoretically by calculation as per standards.

Table 4. Required quantity of Materials

\begin{tabular}{|c|c|c|c|}
\hline S.No & Material description & Quantity & Unit \\
\hline 1 & $\begin{array}{c}\text { 9" wall Brick Work } \\
\text { with 12mm thick Cement } \\
\text { mortar 1:6 }\end{array}$ & 10 & $\mathrm{~m} 3$ \\
\hline & Bricks(230x100x73)mm & 9614 & nos \\
\hline & Cement & 1.03 & $\mathrm{~m} 3$ \\
\hline & Fine aggregate & 6.15 & $\mathrm{~m} 3$ \\
\hline
\end{tabular}




\section{Effective Selection of Resources for Construction using Program Tool}

\begin{tabular}{|c|c|c|c|}
\hline 2 & $\begin{array}{c}\text { 4.5” wall Brick Work } \\
\text { with } 12 \text { mm thick Cement } \\
\text { mortar 1:6 } \\
\end{array}$ & 10 & $\mathrm{~m} 3$ \\
\hline & Bricks (230x100x73)mm & 4807 & nos \\
\hline & Cement & 0.39 & m3 \\
\hline & Fine aggregate & 2.31 & $\mathrm{~m} 3$ \\
\hline \multirow[t]{4}{*}{3} & $\begin{array}{c}\text { Hollow Block wall } \\
\text { with } 12 \mathrm{~mm} \text { thick Cement } \\
\text { mortar 1:6 }\end{array}$ & 10 & $\mathrm{~m} 3$ \\
\hline & $\begin{array}{c}\text { Hollow Blocks } \\
(385 \times 150 \times 200) \mathrm{mm}\end{array}$ & 2364 & nos \\
\hline & Cement & 0.79 & m3 \\
\hline & Fine aggregate & 4.76 & $\mathrm{~m} 3$ \\
\hline \multirow[t]{4}{*}{4} & $\begin{array}{c}\text { Solid Block wall } \\
\text { with } 12 \mathrm{~mm} \text { thick Cement } \\
\text { mortar } 1: 6\end{array}$ & 10 & $\mathrm{~m} 3$ \\
\hline & $\begin{array}{c}\text { Solid Blocks } \\
(304.8 \times 203.2 \times 200) \mathrm{mm} \\
\end{array}$ & 2958 & nos \\
\hline & Cement & 1.05 & m3 \\
\hline & Fine aggregate & 6.29 & $\mathrm{~m} 3$ \\
\hline \multirow[t]{3}{*}{5} & $\begin{array}{c}\text { Plastering with } 12 \mathrm{~mm} \text { thick Cement mortar } \\
1: 6\end{array}$ & 10 & $\mathrm{~m} 2$ \\
\hline & Cement & 0.26 & $\mathrm{~m} 3$ \\
\hline & Fine aggregate & 1.54 & $\mathrm{~m} 3$ \\
\hline \multirow[t]{4}{*}{6} & White wash 1st coat & 100 & $\mathrm{ft} 2$ \\
\hline & White cement & 3 & Kgs \\
\hline & Water for smooth surface & 2250 & $\mathrm{ml}$ \\
\hline & Water for rough surface & 1500 & $\mathrm{ml}$ \\
\hline \multirow[t]{4}{*}{7} & White wash 2nd coat & 100 & $\mathrm{ft} 2$ \\
\hline & White cement & 2 & Kgs \\
\hline & Water for smooth surface & 1500 & $\mathrm{ml}$ \\
\hline & Water for rough surface & 1000 & $\mathrm{ml}$ \\
\hline \multirow[t]{3}{*}{8} & Primer coating & 100 & $\mathrm{ft} 2$ \\
\hline & Primer & 2 & Lit \\
\hline & Water & 750 & $\mathrm{ml}$ \\
\hline \multirow[t]{3}{*}{9} & Water paint coating & 100 & $\mathrm{ft} 2$ \\
\hline & Water paint & 2 & Lit \\
\hline & Water & 300 & $\mathrm{ml}$ \\
\hline \multirow[t]{3}{*}{10} & Enamel paint coating & 100 & $\mathrm{ft} 2$ \\
\hline & Enamel paint & 3 & Lit \\
\hline & Thinner & 600 & $\mathrm{ml}$ \\
\hline \multirow[t]{4}{*}{11} & Putty work & 1 & $\mathrm{ft} 2$ \\
\hline & Putty & 5 & Kgs \\
\hline & Water for wet season & 2.5 & Lit \\
\hline & Water for dry season & 2.25 & Lit \\
\hline \multirow[t]{4}{*}{12} & Cement Concrete - M25 & 1 & $\mathrm{~m} 3$ \\
\hline & Cement & 0.4 & m3 \\
\hline & Fine Aggregate & 0.4 & $\mathrm{~m} 3$ \\
\hline & Coarse Aggregate & 0.8 & m3 \\
\hline
\end{tabular}

The above-mentioned data feed in the programming tool and as per the input of quantity of work the output will be displayed

\section{ANDROID STUDIO}

Android studio is the official IDE (Integrated Development Environment) or tool (layman terms) for developing applications exclusively for the Android platform. Android studio is a framework that includes every tool necessary to develop Android applications and games. Technically, it is an official IDE (Integrated Development Environment) for facilitating app and game development. It simplifies and auto-generates Java files, directories (folders), placeholder icons, manifest file, XML files, and many other things. G.RANJITH (17CSR170) and S.PRASANNA (17CSR152) of

Computer Science and Engineering students' batch 2017 2021, Kongu Engineering College Perundurai who were technicians helped to prepare the programming tool. In the future scope of the project the tool subject to optimization and planned to upload in Google play store.

\section{IX.RESULT AND DISCUSSION}

The tool is helpful for preliminary estimation to do quantity takeoff, resource selection and allocation for respective works. For fixing the calendars and working time for the resources. Planning the resources for completing the work like that already scheduled. For forecasting the requirements of the above-mentioned

resources to complete a set of work. It is helpful to implement the concept of crashing by adding more resources to a particular work to finish the work within the estimated duration. Figure 1 shows the interfaces of Android mobile application.

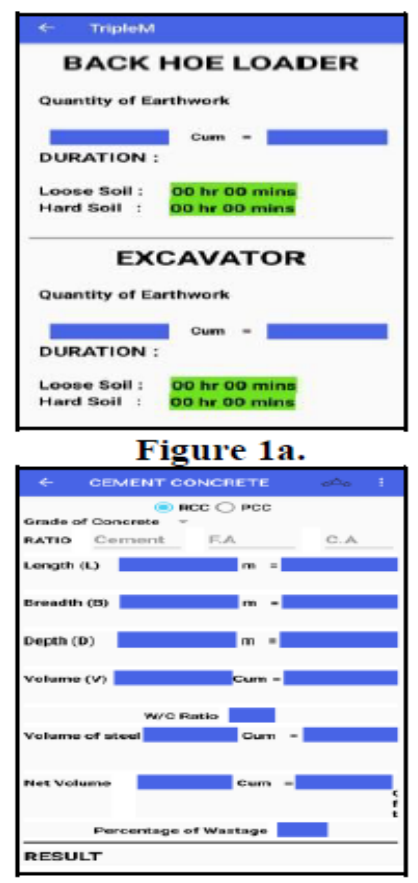

Figure 1c.

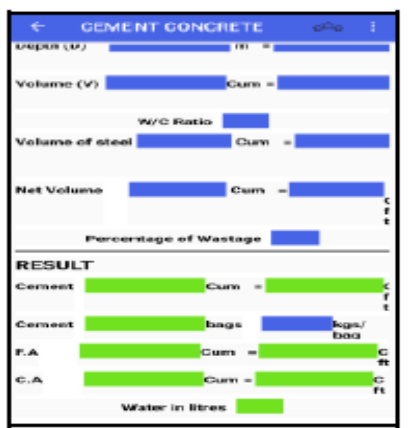

Figure 1b.

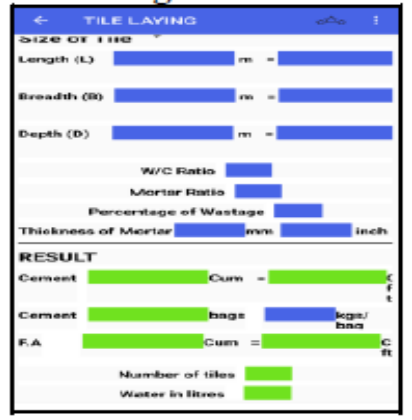

Figure 1d.
Published By:

Blue Eyes Intelligence Engineering \& Sciences Publication

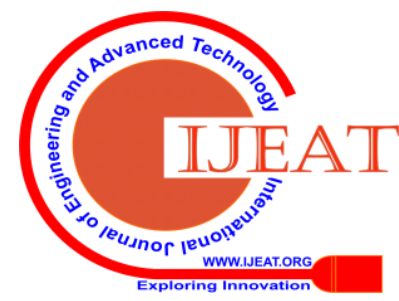




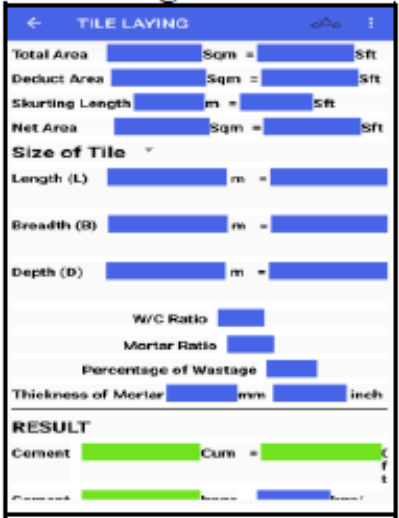

Figure 1e.

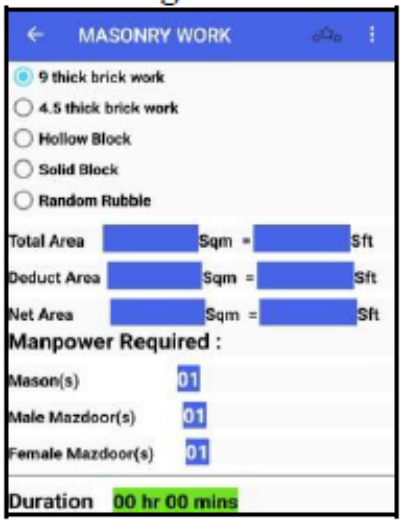

Figure 1g.

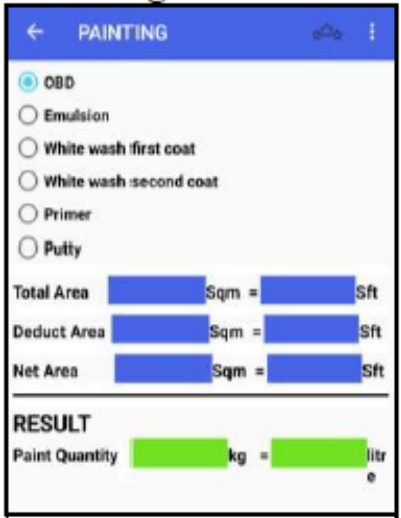

Figure 1f.

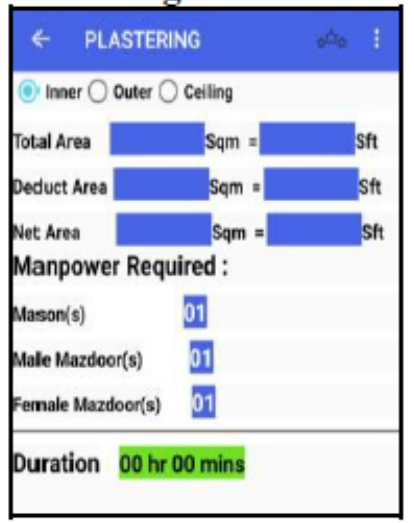

Figure 1h.
Figure 1. Interfaces of Program tool

\section{CONCLUSION}

By this user-friendly tool site engineers, in-charges, quantity surveyors, project managers and any stakeholders of construction will feel easier to find out their resources as effectively. The requirement of resources that predefined before the work incipient as approximately. Accurate values will not be defined and it depends on the nature of site conditions. Dishonest activities will find out in the utilization of the resources. Bills were prepared after the completion of work with the exact quantity of resource usage. But preliminary estimation is done by approximate resource taken off, hence this program tool helps for it. The program tool android mobile application will available on google play store before March 2020, hence everyone can access free of cost and without internet data usage after download. Utilizing the tool by input the right data gives the exact output result. By using the tool regularly in every task of work for selecting the resources effectively will results in a huge impact in the overall time and cost of the project.

\section{REFERENCES}

1. Arditi, D. and Mochtar, K. (2000) Trends in Productivity Improvement in the US Construction Industry,Journal of Construction Management and economics, Vol. 18.

2. Mr. James D. Whiteside II, PE, Cost Engineering Consultant, ConocoPhillips [2006]. AACE International Transactions

3. Flyvbjerg B, Skamris Holm MK, Buhl SL (2004) "What Causes Cost Overrun in Transport Infrastructure Projects?", Transport Reviews, Vol. 24, No.1, pp. 3-18.

4. Ghulam Abbas Niazi, Noel Painting, (2017) "Significant Factors Causing Cost Overruns in the Construction Industry in Afghanistan", Procedia Engineering, Vol. 182, pp. 510-517.

5. Ahmed, Syed M, Salman Azhar, M. Castillo, and P. Kappagantula (2002) "Construction delays in Florida: An empirical study", Final report. Department of Community Affairs, Florida, US.

6. Nabil Al-Hazim, Zaydoun Abu Salem, Hesham Ahmad (2017) "Delay and Cost Overrun in Infrastructure Projects in Jordan" Procedia Engineering, Vol. 182, pp. 18 - 24.

7. Cost and time control of construction projects: inhibiting factors and mitigating measures in practice. Yakubu adisa olawale and ming sun

8. Frimpong, Yaw, Jacob Oluwoye, and Lynn Crawford (2003) "Causes of delay and cost overruns in construction of groundwater projects in a developing countries; Ghana as a case study", International Journal of project management, Vol. 21, No.5, pp. 321-326.

9. Delay and Cost Overruns in Vietnam Large Construction Projects A Comparison with Other Selected Countries.

\section{AUTHORS PROFILE}

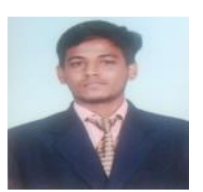

Mr.G.Dhanasekar, pursuing M.E Construction Engineering and Management, Department of Civil Engineering, Kongu Engineering College, Erode, Tamilnadu, India. $\mathrm{He}$ can be reached at Email: dhana7284.7@gmail.com
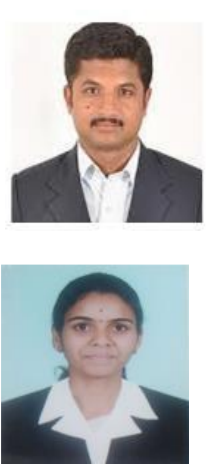

Ms.L.Madhumitha, pursuing M.E Construction Engineering and Management, Department of Civil Engineering, Kongu Engineering College, Erode, Tamilnadu, India. She can be reached at Email: madhulogu1996@gmail.com

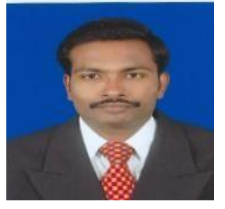

Dr.P.Karthikeyan working as Assistant Professor in Kongu Engineering College, Erode, Tamilnadu in the stream of department of Management Studies. He published 6 international journals and 10 National journals. He can be reached at Email: ptp_karthi@kongu.ac.in

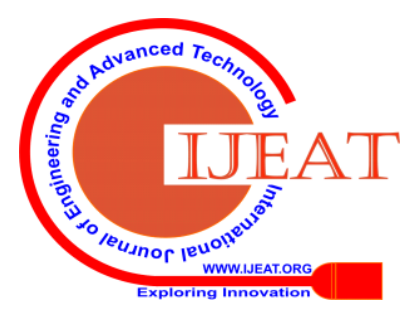

